\title{
Research on the Economic Effects of Regional Inbound Tourism Based on Internet Diffusion
}

\author{
Guanghai Tang ${ }^{12, a^{*}}$ and Ruili Chu ${ }^{2, b}$ \\ ${ }^{1}$ Xijing University, Xian 710062, China \\ 2 Foreign Studies Department, Weinan Normal University, Weinan 714099, China

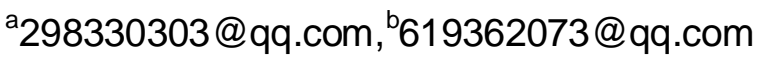

\begin{abstract}
Keywords: Internet diffusion; Inbound tourism; Panel data; Tourism economy
\end{abstract}
\begin{abstract}
Using the Internet to transform the tourism model and enhance the ability and experience of online travel service is an important measure to develop the Intelligent Tourism in many places. For empirical analysis, a panel data model was set up based on the relationship between Internet resources such as Internet users, domain names, websites and regional inbound tourism revenue in China's 31 provinces in 2003-2015. The result shows that the Internet plays a positive role in promoting China's inbound tourism economy; Internet users penetration rate and the increase in the number of sites are relatively significant on China's inbound tourism economic development; an obvious regional difference was appeared by the impact of Internet on regional inbound tourism economy; And the lag effect model shows that the Internet lag effect on inbound tourism economy reaches the maximum in the 4 th year.
\end{abstract}

\section{Introduction}

The information technology represented by the Internet has become a tool of new productivity and it is one of the important resources of economic development. As a typical universal technology, the Internet presents obvious externalities and spillover effects ${ }^{[1]}$, and it has a complex and far-reaching impact on the economy and society. The Internet, as the representative of technology progress in twenty-first Century, has been widely used. As a result, transaction costs are reduced, production efficiency improved, and convenience provided for consumers ; the diffusion of the Internet has promoted spillover of the local tourism information. And it has a strong external influence on consumers outside the region; Internet diffusion effect, due to resource differences between the regional economic environment and the Internet diffusion, has regional differences ${ }^{[2]}$. The application of Internet has created more business opportunities and economic structure adjustments, such as e-commerce and online travel transactions ${ }^{[3]}$.

Tourism, as a Pathfinder of economic development, has attracted much attention ${ }^{[4]}$. The development of Internet meets effectively the needs of tourism demands, especially for it's feature of diversify and individuation. Internet is paving a way for the development of tourism naturally ${ }^{[5]}$.

The application of Internet can greatly extend and deepen tourists' experience, such as online payment, virtual tourism, and cross-border integration consuming between tourism and education, culture, entertainment and so on ${ }^{[6]}$.

The study on the theme of "the Effect of Internet on Tourism" has mainly focused on tourism behavior $^{[7]}$, tourism marketing or distribution ${ }^{[8]}$, tourism image ${ }^{[9]}$, wisdom tourism ${ }^{[10]}$, convenient tourism payment, online booking, and service quality of tourism and so on. It indicates that the Internet and tourism economy is closely related with each other. There is still a long way to go, though. And certain empirical research is needed in the following regards, such as: how to measure the contribution of Internet to the development of tourism economic; how to evaluate the influence of various factors of Internet on tourism economy. It is more typical to study the influence of Internet Diffusion on inbound tourism economy and its hysteresis, because of the spatial breakthrough effect ${ }^{[11]}$ of Internet diffusion and the possibility of lagging. Therefore, it is very necessary to establish a panel data model based on the relationship between Internet Diffusion factors and inbound tourism economy. 


\section{Variable Selection}

Internet Diffusion. The degree of Internet Diffusion is closely related to local Internet infrastructure and penetration rate of cyber citizen. Some experts, such as Zhang Yue, made use of evaluation index of Internet, which including the Internet popularity rate, broadband port number, page number, IP address, domain name and the number of sites, to study it's influence on economy ${ }^{[12]}$. It turned out that the number of web pages, broadband port number, the number of IP addresses has little influence on economy ${ }^{[13]}$. Experts, such as Zhongwei Sun, found that correlation, between domain name, the number of sites and the growth of GDP is not very obvious ${ }^{[14]}$. However, tourism is connected with Internet naturally. Domain name and website are very important for inbound tourism economy by which tourists collect relevant information or online booking demand. According to the Internet demand of inbound tourism, this thesis aims to evaluate regional Internet development level, and further reflects the spread of Internet based on three factors: the Internet penetration rate, the number of domain names and web sites. Certain related variables data of Internet diffusion come from "the Statistic Report of Internet Development" of year 2004-2014, which was published in CNNIC.

Regional Inbound Tourism Economy. Regional inbound tourism economy can be measured by two factors, one is inbound tourism number and the other is inbound tourism foreign exchange revenue. Due to the lack of inbound tourism number data, more relevant literature used inbound tourism foreign exchange income to reflect regional inbound tourism economy [17]. The income of inbound tourism foreign exchange was calculated from 2003 to 2015 by three factors from "The Yearbook of China Tourism Statistics"from 2004 to 2016. They are the regional tourism foreign exchange income and its tourism development index and the number of year-end population in each region.

\section{Model Construction}

The per capita inbound tourism foreign exchange income ( Ptr ) was used as the interpreted variable; Internet penetration rate ( Pjl ), the number of domain names ( Pym ) and website number ( Pwz ) were used as explanatory variables. In order to eliminate the possible variance between variables, and to reflect the elastic relationship between Internet diffusion and inbound tourism revenue, the Panel data model is constructed by taking the natural logarithm of the variable,as follows.

$$
\begin{aligned}
& \operatorname{LnPtr}_{i t}=\alpha+\eta_{i}+\beta_{1} \operatorname{LnPjl}_{i t}+\beta_{2} \operatorname{LnPym}_{i t}+\beta_{3} \operatorname{LnPwz_{it}}+v_{t}+\varepsilon_{i t} \\
& i=1,2, \cdots, 31 ; t=2003,2004, \cdots, 2015
\end{aligned}
$$

In the form (1), Ptr refers to the per capita income of inbound tourism; Pjl represents the prevalence of Internet users; Pym represents the number of domain names per 10,000 persons; Pwz represents the number of websites per 10,000 people; $\beta_{1} 、 \beta_{2} 、 \beta_{3}$ is the coefficient of $L n P j l$ 、 LnPym 、LnPwz, which indicates the elastic coefficient of Internet diffusion variable on the per capita inbound tourism revenue. ${ }^{\alpha}$ refers to the intercept; ${ }^{\eta_{i}}$ reflects the impact of individual effects in different provinces; ${ }^{{ }^{t}}$ reflects the time point effect of different years; ${ }{ }_{i t}$ is a random error term. The descriptive statistics of the main variables in the model are shown in table 1. 
Table 1. Descriptive Statistics of Main Variables

\begin{tabular}{|c|c|c|c|c|c|c|c|}
\hline $\begin{array}{l}\text { Variab } \\
\text { le }\end{array}$ & $\begin{array}{l}\text { Observ } \\
\text { ed Value }\end{array}$ & $\begin{array}{l}\text { Mean } \\
\text { Value }\end{array}$ & $\underset{\mathrm{n}}{\text { Media }}$ & $\begin{array}{l}\text { Standa } \\
\text { rd } \\
\text { eviation }\end{array}$ & $\begin{array}{r}\text { Minim } \\
\text { um Value }\end{array}$ & $\begin{array}{l}\text { Maxim } \\
\text { um Value }\end{array}$ & $\begin{array}{c}\text { Confiden } \\
\text { ce } \\
\text { Level }(95 \%)\end{array}$ \\
\hline LnPtr & 403 & $\begin{array}{l}-1.917 \\
250\end{array}$ & $\begin{array}{l}-1.885 \\
400\end{array}$ & $\begin{array}{l}1.5057 \\
70\end{array}$ & $\begin{array}{l}-6 . \\
40\end{array}$ & $\begin{array}{l}1.0128 \\
00\end{array}$ & 0.175777 \\
\hline LnPjl & & $\begin{array}{l}-1.578 \\
117\end{array}$ & $\begin{array}{l}-1.312 \\
100\end{array}$ & $\begin{array}{l}0.8753 \\
91\end{array}$ & $\begin{array}{l}-3.841 \\
000\end{array}$ & $\begin{array}{l}-0.276 \\
200\end{array}$ & 0.000000 \\
\hline $\begin{array}{l}\mathrm{LnPy} \\
\mathrm{m}\end{array}$ & & $\begin{array}{l}3.2338 \\
05\end{array}$ & $\begin{array}{l}3.3743 \\
00\end{array}$ & $\begin{array}{l}1.6853 \\
37\end{array}$ & $\begin{array}{l}-1.115 \\
000\end{array}$ & $\begin{array}{l}7.7130 \\
00\end{array}$ & 0.059374 \\
\hline LnPwz & 403 & $\begin{array}{l}1.8566 \\
86\end{array}$ & $\begin{array}{l}1.7710 \\
00\end{array}$ & $\begin{array}{l}1.2672 \\
09\end{array}$ & $\begin{array}{l}-1.115 \\
000\end{array}$ & $\begin{array}{l}5.4681 \\
00\end{array}$ & 0.000045 \\
\hline
\end{tabular}

In the model test, first, in order to determine stability among the variables, the unit root test should be done, thus avoiding the false regression of model; then, the cointegration test should be done for the judgment of long-term equilibrium relationship among variables; finally, the relationship between Internet diffusion and China's inbound tourism and economic development could be verified by using $F$ test and Hausman test, choosing regression type of fit panel data model, and estimating parameters.

\section{Empirical Test}

Unit root test. The spurious regression problems of model could be done by using the unit root test. The results of the unit root test are shown in table 2. It is significant both the corresponding index level of LnPtr, LnPym, LnPwz and the corresponding index of difference value in $1 \%$ and $5 \%$. There are original hypothesis of root unit about variables. However, two indexes, PS and ADF-Fisher in LnPjl, are not significant. Therefore, the unit root hypothesis can not be rejected, which indicates the unstability of the variable. The first-order differential test results show the existing unit root hypothesis of the rejected variables, which indicates two facts: one is that LnPjl variables are first-order single whole sequence, the other is that the model can proceed with cointegration analysis.

Table 2. Results of Unit Root Test

\begin{tabular}{|c|c|c|c|}
\hline & \multicolumn{3}{|c|}{ Horizontal Level } \\
\hline \multirow{2}{*}{ variables } & LLC & IPS & ADF-Fisher \\
\hline \multirow{2}{*}{ LnPtr } & $-13.9986^{* * *}$ & $-10.3922^{* * *}$ & $210.512^{* * *}$ \\
\cline { 2 - 4 } & $(0.0000)$ & $(0.0000)$ & $(0.0000)$ \\
\hline \multirow{2}{*}{ LnPj1 } & $-11.8618^{* * *}$ & $-3.0821^{* * *}$ & $93.2243^{* * *}$ \\
\cline { 2 - 4 } & $(0.0000)$ & $(0.001)$ & $(0.0063)$ \\
\hline \multirow{2}{*}{ LnPym } & $-10.4513^{* * *}$ & $-5.12042^{* * *}$ & $118.746^{* * *}$ \\
\cline { 2 - 4 } & $(0.0000)$ & $(0.0000)$ & $(0.0001)$ \\
\hline \multirow{2}{*}{ LnPwz } & $-10.6694^{* * *}$ & $-4.82896^{* * *}$ & $115.928^{* * *}$ \\
\cline { 2 - 4 } & $(0.0000)$ & $(0.0000)$ & $(0.0000)$ \\
\hline
\end{tabular}

Cointegration Test.Cointegration test can be used to analyze the long-run equilibrium relationship among variables. The method of Pedroni Cointegration Test is commonly used in panel data model, and cointegration test statistic is constructed on the basis of regression residuals. The results are shown in table 3. Pedroni pointed out that the result of Panel ADF and Group ADF 
should be adopted when conflict appeared because of the relatively short sample period $(\mathrm{T} \leq 20)$. In Table 3, except for the two statistics of Panel, Rho and Group Rho, the other statistics are significant at the 5\% level. The Group ADF statistics of LnPtr and LnPjl cointegration test is significant in the 5\% level. Panel ADF statistic is significant at the 1\% level; and cointegration test statistic of Panel ADF and Group ADF about other variables have significance at the level of $1 \%$. It shows that there is a long-term equilibrium relationship among three pairs of variables in Cointegration test.

Table 3. Results of Cointegration Test

\begin{tabular}{|c|c|c|c|c|c|c|c|}
\hline Statistics & Panel v & Panel rho & Panel PP & Panel ADF & Group rho & Group PP & Group ADF \\
\hline $\begin{array}{c}\text { LnPtr and } \\
\text { LnPjl }\end{array}$ & $-3.3087 *$ & -0.0346 & $-18.7920 * *$ & $-6.0910^{* *}$ & 2.8721 & $-9.3205^{* *}$ & $-1.7732^{*}$ \\
\cline { 2 - 8 } & $(0.0266)$ & $(0.5644)$ & $(0.0000)$ & $(0.0000)$ & $(0.9980)$ & $(0.0000)$ & $(0.0381)$ \\
\hline $\begin{array}{c}\text { LnPtr and } \\
\text { LnPym }\end{array}$ & $-1.4429 * *$ & 0.4013 & $-8.5532 * *$ & $-2.4985^{* *}$ & 2.2639 & $-11.4892^{* *}$ & $-5.0520^{* *}$ \\
\cline { 2 - 8 } & $(0.0000)$ & $(0.5847)$ & $(0.0000)$ & $(0.0018)$ & $(0.9882)$ & $(0.0000)$ & $(0.0000)$ \\
\hline $\begin{array}{c}\text { LnPtr and } \\
\text { LnPwz }\end{array}$ & $-1.0687 * *$ & 0.1389 & $-7.2833^{* *}$ & $-1.8334 * *$ & 4.0626 & $-3.0156 * *$ & $-4.4915^{* *}$ \\
\cline { 2 - 8 } & $(0.0000)$ & $(0.8883)$ & $(0.0000)$ & $(0.0003)$ & $(1.0000)$ & $(0.0013)$ & $(0.0000)$ \\
\hline
\end{tabular}

Test and Estimation of Panel Model. The panel data model usually have three kinds of model selection, including Fixed Effects Regression Model, Random Effects Regression Model and Pooled Regression Model. In the F test, the fixed effect model or the mixed estimation model is selected by comparing the test results with the $\mathrm{F}$ distribution value. The fixed effects model or the random effects model is selected by Hansman test. Model fitting effect contrast is shown in table 4 . In F test, $\mathrm{F} 1=76.7987 \succ \mathrm{F}(30,371)=1$ 。Could be calculated based on Sum of Squares of Residuals and $\mathrm{S} 1$ and S3, which indicates that fixed effect model is better than the mixed estimation model; Hansman test value of random effect model is 0.0000 , which shows the fixed effect model is superior to the random effect model. The Fitting Degree of model claims that the fixed effect model $(\mathrm{R} 2=0.943922)$ outperforms the hybrid estimation model $(\mathrm{R} 2=0.595671)$ and the random effects model $(\mathrm{R} 2=0.66576)$.

Table 4. Comparison of Fitting Effect of Panel Data Model

\begin{tabular}{|c|c|c|c|}
\hline & $\begin{array}{c}\text { Fixed Effects } \\
\text { Regression Model }\end{array}$ & $\begin{array}{c}\text { Random Effects } \\
\text { Regression Model }\end{array}$ & $\begin{array}{c}\text { Pooled Regression } \\
\text { Model }\end{array}$ \\
\hline Prob(F-statistic) & 0.000000 & 0.000000 & 0.000000 \\
\hline Hansman & 0.943922 & 0.000000 & 0.595671 \\
\hline $\mathrm{R}^{2}$ & 0.938907 & 0.66576 & 0.592631 \\
\hline Adjusted R & 0.663247 & $368.5341(\mathrm{~S} 3)$ \\
\hline $\begin{array}{l}\text { Sum of Squares of } \\
\text { Residuals }\end{array}$ & $51.11331(\mathrm{~S} 1)$ & $264.9174(\mathrm{~S} 2)$ & 403 \\
\hline Observed Value & 403 & 403 & \\
\hline
\end{tabular}

In the fixed effect model, there are three testing methods: individual, period separately and individual and period double fixation. The results are shown in table 5. 
Table 5. Model Test Results of Individual, Period Fixed, and Individual and Period Double Fixed

\begin{tabular}{|l|c|c|c|c|c|}
\hline & $\mathrm{R}^{2}$ & AdjustedR $^{2}$ & $\begin{array}{l}\text { Regression } \\
\text { Standard } \\
\text { Deviation }\end{array}$ & $\begin{array}{l}\text { Sum of } \\
\text { Squares of } \\
\text { Residuals }\end{array}$ & F Statistics \\
\hline Individual fixed model & 0.943922 & 0.938907 & 0.372181 & 51.11331 & 188.2166 \\
\hline Fixed period model & 0.653832 & 0.640415 & 0.902941 & 315.5224 & 48.7303 \\
\hline $\begin{array}{l}\text { Double fixed model at } \\
\text { individual stage }\end{array}$ & 0.954842 & 0.94915 & 0.339552 & 41.16047 & 167.7452 \\
\hline
\end{tabular}

Compared with R2, it can be seen that the dual fixed model is better in individual period. According to the test results, influence parameters can be estimated of Internet Diffusion on inbound tourism economic development in different regions. The results are shown in table 6.

Table 6. $\quad$ Parameter Estimation Based on Individual Period Dual Fixed Model

\begin{tabular}{|c|c|c|c|c|c|}
\hline Index & $\mathrm{C}$ & $\beta_{1}$ & $\beta_{2}$ & $\beta_{3}$ & D.W \\
\hline Parameter & $\begin{array}{c}1.2478^{* * *} \\
(0.000000)\end{array}$ & $\begin{array}{c}0.4838^{* * *} \\
(0.000000)\end{array}$ & $\begin{array}{c}-0.0817^{*} \\
(0.0815)\end{array}$ & $\begin{array}{c}0.1930^{* * *} \\
(0.0054)\end{array}$ & 0.560710 \\
\hline
\end{tabular}

Note: the brackets are P values; “*” and “***”stands for a phenomenon that it is notable at $10 \%$ and $1 \%$ respectively.

Table 6 shows that parameters is -0.021914 , of the domain name is significant in the level of $10 \%$. Parameters of Internet penetration rate and the number of sites are more significant, and has a better model fitting degree. Thus, the expression of model is worked out as follows:

$$
\begin{aligned}
& \operatorname{LnPtr}_{i t}=1.2478+\eta_{i}+0.4838 \operatorname{LnPjl}_{i t}-0.0817 \operatorname{LnPym}_{i t}+0.1930 \operatorname{LnPwz}_{i t}+v_{t}+\varepsilon_{i t} \\
& \quad i=1,2, \cdots, 31 ; t=2003,2004, \cdots, 2015
\end{aligned}
$$

In Type (2), the intercept is $C,=1.2478$, points out the positive effects of Internet diffusion on the inbound tourism economy; $\beta_{1}=0.4838$ is the elastic coefficient the Internet penetration rate on inbound tourism foreign exchange earnings, which indicates that the Internet penetration rate increased by $10 \%$, the per capita of inbound tourism income increased by about $4.838 \%$; $\beta_{3}$ $=0.1930$ is elasticity coefficient of Internet website on Tourism foreign exchange earnings, which shows Internet sites increased by 10\%, inbound tourism foreign exchange earnings increased by about $1.93 \%$ per capita.

Result Analysis. According to the above model, the individual effects in different regions are shown in table 7 . In 31 provinces, municipalities and autonomous regions, the influence of the individual effect shows significant regional differences, mainly due to the differences of Internet diffusion effect on inbound tourism income which were made by tourism resources, regional Internet infrastructure, economic environment and other factors. There are 17 areas whose influence is positive. Most of them are the areas who has advanced economy and rich tourism resources. It turned out that knowledge spillovers effects of Internet Diffusion is more significant in economically developed areas. Another 14 areas whose influence is negative. Most of them are the areas whose economy is not developed or whose tourism resources is needy. There are two cities, Shanghai and Beijing, whose effect is significant which is more than 1.9. There are three cities, Guangdong, Tianjin, Fujian, whose effect is more than 1.0. 
Table 7. Individual Effects in Different Regions

\begin{tabular}{|c|c|c|c|}
\hline Regions & $\eta$ & Regions & $\eta$ \\
\hline Shanghai & 1.990942 & Shandong & 0.009663 \\
\hline Beijing & 1.975208 & Anhui & -0.223337 \\
\hline Guangdong & 1.490959 & Xijiang & -0.287404 \\
\hline Tianjin & 1.454191 & Hunan & -0.409865 \\
\hline Fujian & 1.187155 & Hubei & -0.422435 \\
\hline Zhejiang & 0.992209 & Jilin & -0.426645 \\
\hline Yunnan & 0.828853 & Shanxi & -0.685599 \\
\hline Xizang & 0.809419 & Jiangxi & -0.726204 \\
\hline Jiangsu & 0.792251 & Sichuan & -0.896628 \\
\hline Liaoning & 0.653495 & Guizhou & -1.038905 \\
\hline Hainan & 0.580329 & Henan & -1.142234 \\
\hline Inner Mongolia & 0.563756 & Hebei & -1.174585 \\
\hline Shaanxi & 0.407666 & Qinghai & -1.475271 \\
\hline Chongqing & 0.257731 & Gansu & -2.454589 \\
\hline Guangxi & 0.157253 & Ningxia & -2.860249 \\
\hline Heilongjiang & 0.072868 & \multicolumn{2}{|c}{} \\
\hline
\end{tabular}

Note: "*", "**" and "***" stand for the significance of level 10\%, 5\% and $1 \%$ respectively.

Table 8 reflects the time point effect, and the time impact factor in 2003 and 2015 is generally increasing year by year, with 2008 and 2010, as the dividing line and showing obvious phase characteristics. Before 2008, China's Internet users, domain name and website, generally speaking, developed rapidly. and the effect of time is increasing overall. But some adjustments was made from 2008 to 2010. After 2010,China's Internet penetration rate reached more than $25 \%$, and the number of sites increased, Services deepened, the time point effect increased gradually and became stable. Especially since 2010, China has gradually entered the mobile Internet era. Internet applications, with it's rapid development, nurtures the great impact on inbound tourism economy gradually.

Table 8. Time Point Effects in Each Year

\begin{tabular}{|c|c|c|c|}
\hline Year & $v_{t}$ & Year & $v_{t}$ \\
\hline 2003 & -0.576805 & 2010 & -0.024553 \\
\hline 2004 & -0.207645 & 2011 & 0.109636 \\
\hline 2005 & 0.07804 & 2012 & 0.148832 \\
\hline 2006 & 0.162901 & 2013 & 0.129558 \\
\hline 2007 & 0.23603 & 2014 & 0.078361 \\
\hline 2008 & -0.146556 & 2015 & 0.153514 \\
\hline 2009 & -0.141314 & & \\
\hline
\end{tabular}

The value of D.W=0.560710, in the model is positive, which indicates that Internet diffusion has a certain influence on China's foreign exchange income of inbound tourism, but it also has a lag effect. Table 9 is the test results of the Internet Diffusion variables for it's lagging behind 1 to 4 years. The value of D.W is relatively stable within the lag phase of 1 to 4 year, increases gradually, and reaches the maximum in the fourth years; The intercept reaches the maximum in the third year in the period of it's lag phase, adjusts highly in the fourth year and decreases significantly in the fifth year. In the lag phase of 1 to 4 year, the impact of the Internet penetration rate on inbound 
tourism is increasing year by year, reaches the maximum in the fourth year, and begins to decrease from the fifth year. The effect of the domain name and website on inbound is not obvious. Because of the limited space, the lagging effect of various regions is no longer discussed here.

Table 9. Test Results of 1-5 Year Lag Phase

\begin{tabular}{|c|c|c|c|c|c|}
\hline & Lag for 1 year & Lag for 2 year & Lag for 3 year & Lag for 4 year & Lag for 5 year \\
\hline C & 1.465784 & 1.507548 & 1.526041 & 1.657000 & 1.540063 \\
\hline$\beta_{1}$ & 0.425192 & 0.400528 & 0.40094 & 0.366417 & 0.154632 \\
\hline$\beta_{2}$ & -0.115092 & -0.093346 & 0.017506 & -0.016839 & -0.090924 \\
\hline$\beta_{3}$ & 0.154446 & 0.117715 & -0.002817 & -0.014287 & -0.033763 \\
\hline R2 & 0.954504 & 0.955428 & 0.95807 & 0.962718 & 0.969696 \\
\hline AR2 & 0.948382 & 0.948974 & 0.951474 & 0.956268 & 0.96384 \\
\hline D.W & 0.514455 & 0.588118 & 0.659829 & 0.786609 & 0.681109 \\
\hline
\end{tabular}

\section{Conclusions}

Data and empirical test of corresponding indicators of Internet diffusion on inbound tourism foreign exchange income is collected and made respectively from 2003 to 2015 year. The main conclusions are as follows: There is a long-term equilibrium relationship between Internet diffusion variables and China's inbound tourism foreign exchange earnings. The Internet penetration rate and the number of sites has a positive effect on China's inbound tourism economy, and the growth of domain name is not significant. In the long run, since the Internet penetration rate has increased by $10 \%$, the per capita inbound foreign exchange income of inbound tourism has increased by about $4.838 \%$; the number of websites increased by $10 \%$, and the per capita foreign exchange income of inbound tourism has increased by about $1.93 \%$. Judging from the time effect, the effect of Internet Diffusion on inbound tourism economy in China shows a general trend of growth.

The rate of Internet penetration and the number of websites in different regions of our country show regional differences. The influence of Internet Diffusion on inbound tourism is more obvious in developed areas. There are 17 regions whose Internet diffusion effect is positive, mainly in the eastern developed regions or areas with rich tourism resources. There are 14 regions whose Internet diffusion effect is negative, mainly in the Midwest areas whose economy is underdeveloped relatively or areas whose tourism resources are not famous internationally. The individual effects are the most obvious in Shanghai and Beijing, which is more than 1.9, four in Tianjin. And the individual effects are more than 1 in Guangdong, Tianjin and Fujian .

With the development of Internet technology, the proliferation of Internet users and websites has a cumulative effect and lag effect on China's Inbound Tourism Foreign Exchange earnings. During the lag period, the effect of Internet diffusion was gradually strengthened, reaching its maximum in the fourth years and weakening in the fifth year. The Internet has lag diffusion, partly because new users mainly in young students, and with limited contact surface and publicity. The effect of economic growth also need time to reflect and the new site also has a process of promotion and publicity.

Based on the above conclusions and the test results, suggestions are made as follows:

The government should increase the investment of infrastructure through the network, increase the network access port, reduce broadband tariff, reduce mobile phone Internet tariffs and other measures to further improve the proportion of Internet users, and promote the use of the diffusion of the internet. In order to play a better role in promoting the economic growth of inbound tourism 
through Internet proliferation in China, the government should promote and popularize the Internet in the less developed areas as soon as possible, narrow the digital gap between eastern and western regions, urban and rural areas.

In order to meet the needs of the tourism resources of inbound tourists, promote economic growth of inbound tourism, the government should encourage and support the scenic spots, travel agencies, hotels, restaurants and other tourism related industries to build their own official websites actively and increase efforts to promote online travel platform, integrated service platform. With the help of "the Belt and Road" strategy implementation,in order to make use of the effect of websites, make up economic growth differences of inbound tourism in the Midwest, a large number of tourism brand websites should be established in China's central and western areas.

In order to promote the effect of Internet diffusion, a long-term and sustained investment is needed in the construction of brand website of Internet infrastructure and tourism resources, and the promotion of Internet diffusion because of lag effect of Internet. In order to better play the Internet proliferation effect, enhance inbound tourism foreign exchange income, thereby promoting regional economic growth, Internet investment should be increased greatly, and tourist attractions, routes, regions should be created in the Midwest.

\section{References}

[1] Androutsos A. Access link bandwidth externalizations and endogenous Internet growth: a long-run economic approach[J]. International Journal of Network Management, Vol.21(2011)No. 1,P.21.

[2] Anfeng Xu. Research on tourism development based on Internet: A Case of C-trip[J]. China Business\& Trade, Vol.1(2009) No.19.P.140.

[3] Zhang Chao-zhi ,You Wang . On the Impact of Internet on the Distribution Channels in Tourism Destination: A Case Study of Huangshan[J] . Tourism Tribune,Vol.1(2012) No.03, P52.

[4] Xu Jinhai, Wang Qun . Research on the integration of tourism industry in "Internet+"[J]. Research on Financial and Economic Issues, Vol.11(2016)No.03,P123.

[5] Liang Xisao, Liming Zhao. The Tourism Destination Image of Taiwan Disseminated on Internet: Based on A Content Analysis of Travelrelated Websites across TaiwanStraits[J]. Tourism Tribune, Vol.07(2009).No.03,P75.

[6] Zhang Lifeng, Liu Binde. Analysison Influence of Tourism Consumption on Economic Growth in China[J]. Technology Economics, Vol.12(2009) No.05,P81.

[7] Li R, Yi H M. . Internet boost the economic growth of mainland China? Discovering Knowledge from Our World Wide Web[J]. Global Business and Management Research, Vol.3(2011) No.4, P345.

[8] Li Liwei , Jing Feng. Relationship between Internet Diffusion and Economic Growth: Empirical Research Based on Panel Data of China's 31 Provinces[J]. Journal of Beijing Technology and Business University (Social Sciences), Vol.01 (2013) No.03,P120.

[9] Du Peng \& Yang Lei . The Research on Framework System and Development Strategy of Smart Tourism[J]. Science and Technology Management Research, Vol.23(2013) No.3,P 44.

[10] Pin Lv\& Shuhuan Zhang. Study on regional differences of Internet diffusion in China[J]. Special Zone Economy, Vol.1(2007) No.02,P256.

[11]Xiang Yucheng . The development of tourism industry in "tourism + Internet"[J]. Tourism Tribune, Vol.21(2016) No.05, P8.

[12] Zhang Yue, Li Qi . Empirical Analysis of Internet Factors on the Economic Development of 
Chinese Provinces[J]. Journal of ShanXi Finance and Economics University, Vol.01(2008) No.06, P38.

[13]Liao Yanjun, Cai Rui , Liu Lingling, Wang Qing . Study of Internet Tourism Dispute Resolution Mechanism Based on the Internet Cases[J]. Journal of Yanshan University, Vol.01(2015) No.04,P133.

[14] Sun Zhongwei, Zhang Bing, Wang Yang, Niu Jianqiang. Relationship between Internet Resources and Provincial Economy Development in China[J]. Geography and Geo-Information Science, Vol.3 (2010)No.03,P44. 